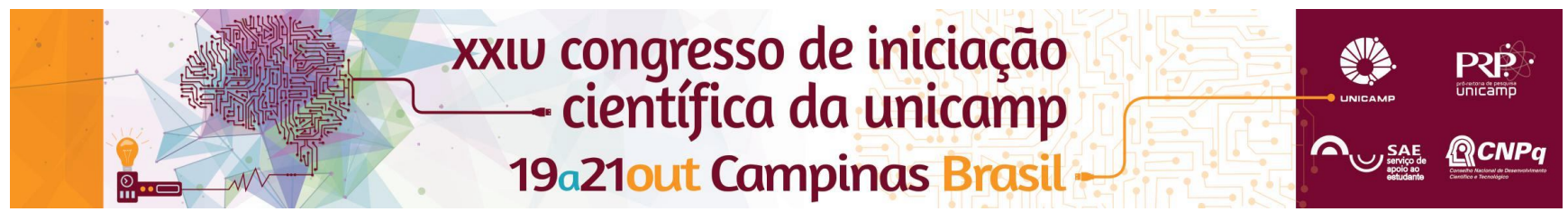

\title{
Analysis of silica dissolution from rice husk ash for geopolymer production: the storage time
}

\author{
Felipe S. Pontes*, Rodrigo H. Geraldo, Gladis Camarini.
}

\begin{abstract}
In the production of geopolymer the use of commercial sodium silicate is very common; however this material causes several environmental impacts during its production. The extraction of silica from rice husk ash by using the alkaline lixiviation method is an alternative. In this study the storage time was analysed in the production of a source of dissolved silica more environmental friendly. The results showed all these conditions are important in the production of the alternative sodium silicate.
\end{abstract}

\section{Key words:}

Alkaline activation, geopolymers, sustainability.

\section{Introduction}

The ordinary Portland cement (OPC) is one of the most used materials in the world and its production represents $5 \%$ of the total $\mathrm{CO}_{2}$ emissions ${ }^{1}$. Geopolymers are an environmental friendly alternative to OPC, with similar performance ${ }^{2}$. However, the production of geopolymer still faces challenges, such as the origin of the silica employed in the production of the binder.

Rice husk ash (RHA) is a by-product of rice harvesting, and contains high levels of silica, which can be extracted by alkaline lixiviation ${ }^{3}$. This research aimed to evaluate the influence of the storage time of a mixture containing $\mathrm{RHA}$ and $\mathrm{NaOH}$ solution in the content of the dissolved silica dissolution.

\section{Materials and Methods}

The materials used were the $\mathrm{RHA}$, the $\mathrm{NaOH}$ and the water. It was used a magnetic stirring with heating for the dissolution of $\mathrm{NaOH}$ and RHA. The mixture was made and there were two procedures: with and without storage of the blend. It was evaluated the influence of the storage of the mixture to dissolve the silica to make this sodium silicate: no storage (just after mixing) and 2 days storage. After this period, the material passed for a process of heating and stirring in a magnetic stirrer with heating. The temperature of heating was $80^{\circ} \mathrm{C} \pm 5^{\circ} \mathrm{C}$. This procedure was important to make the sodium silicate.

The mixture used was the same for both determinations.

The dissolution rates were measured using gravimetric analysis.

\section{Results and Discussion}

The results of the quantity of dissolved silica in the mixture are presented in Figure 1 and Figure 2. The most relevant factor was the storage time.

The stirring temperature of $80^{\circ} \mathrm{C}$, heating and stirring time increased from 0 minutes to 150 minutes. With those same conditions, the storage time alone allowed an increase of $30 \%$ in the dilution of silica, going from $57 \%$ to $87 \%$ on the highest peaks.
Figure 1 - Silica dissolution - 0 days of storage

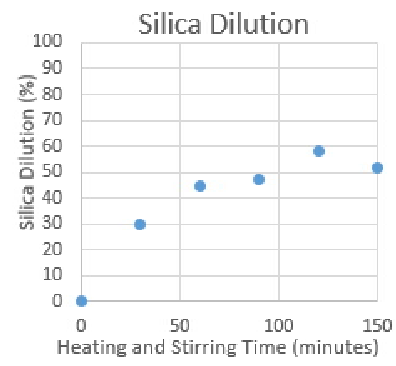

Figure 2 - Silica dissolution - 2 days of storage

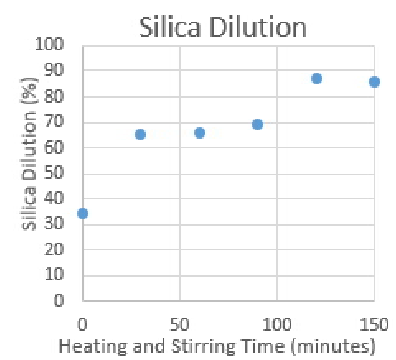

\section{Conclusions}

The study showed that the storage time is a key factor for satisfactory silica extraction rates from rice husk ash. Rates of $87 \%$ in dissolution were obtained, thus, indicating that the method is efficient and very costeffective. This material could replace the use of commercial sodium silicate in the production of geopolymers.

\section{Acknowledgement}

The authors thank CAPES and CNPq for the financial support, Daniel Bueno and LARES for the technical support.

[1]CARVALHO, M. B. M. Impactos e conflitos da produção de cimento no Distrito Federal. 2008. 187 p. Dissertação (Mestrado em Desenvolvimento Sustentável) - Universidade de Brasília, Distrito Federal, 2008.

[2] DAVIDOVITS, J. Geopolymers and Geopolimeric Materials. Journal of Thermal Analysis, Vol. 35 (1989) 429-441.

[3] FERREIRA, M. J. . Obtenção de silicato de sódio por lixívia alcalina a partir da cinza da casca de arroz (cinza da casca de arroz) para uso como defloculante, Universidade Federal de Santa Catarina, p. 11-32 2013 